\title{
Nutritional and endocrinological manipulation of lean deposition in forage-fed steers
}

\author{
BY J. M. DAWSON, P. J. BUTTERY, M. J. LAMMIMAN, J. B. SOAR \\ AND C. P. ESSEX \\ Department of Applied Biochemistry and Food Science, University of Nottingham School of \\ Agriculture, Sutton Bonington, Loughborough, Leics LEI2 5RD \\ AND M. GILL* AND D. E. BEEVER \\ AFRC Institute for Grassland and Animal Production, Hurley Research Station, Hurley, \\ Maidenhead, Berks SL6 5LR
}

(Received 9 July 1990 - Accepted 4 January 1991)

\begin{abstract}
The effect of supplementing grass silage with fishmeal on growth, muscle composition and the rate of muscle protein synthesis was investigated in young Friesian steers with and without oestradiol implants. The effect of the $\beta$-adrenergic agonist cimaterol was simultaneously investigated in animals fed on silage alone. Treatments lasted for 9 or 10 weeks. Fishmeal supplementation significantly increased animal growth rates $(P<0.001)$ and the weights of three dissected muscles $(P<0.001)$ compared with the silage-fed controls. These effects were further enhanced in animals also implanted with oestradiol. Muscle weights expressed as a proportion of body-weight were increased by fishmeal, suggesting that protein deposition had been enhanced. No further increase in the proportional muscle weights was obtained with oestradiol. Muscle dry matter content tended to be increased in both implanted and nonimplanted animals receiving fishmeal compared with controls, but the proportions of protein, fat and ash were relatively constant. The intramuscular lipid composition was slightly altered by fishmeal. Muscle protein fractional synthetic rates (FSR), measured by continuous infusion of $\left[{ }^{3} \mathrm{H}\right]$ tyrosine, were increased by fishmeal in all three muscles of both implanted and non-implanted animals. There were no differences, however, due to oestradiol, over non-implanted fishmeal animals. This suggests that oestradiol may increase muscle accretion by reducing protein degradation rate. Cimaterol significantly increased longissimus dorsi $(P<0.05)$ and vastus lateralis $(P<0.01)$ muscle weights but had no effect on semitendinosus muscle weight or live-weight gain. The proportion of protein was increased $(P<0-001)$ and the fat content reduced $(P<0.05)$ in all three muscles but intramuscular lipid composition was not markedly affected. Whilst methylhistidine : creatinine excretion was reduced by cimaterol, FSR were increased in the $I$. dorsi and $v$. lateralis muscles suggesting $\beta$-agonists have effects on both protein synthesis and protein degradation.
\end{abstract}

Carcass manipulation: Protein turnover: Muscle composition

The opportunity for a growing animal to increase the net deposition of muscle protein is influenced by many factors, with the quantity of protein supplied in the diet and the relative rates of muscle protein synthesis and degradation being of crucial importance. In beef cattle fed on predominantly silage diets, it is recognized that one major limitation to growth is protein supply and in this respect the studies of Gill et al. (1987) and others have shown marked tissue protein anabolic responses to the use of fishmeal supplements. However, in this study a marked nutritional-endocrinological interaction was detected, with oestradiol stimulating a positive protein anabolic response only in the presence of significant

\footnotetext{
* Present address: NRI, Central Ave, Chatham Maritime, Kent NE4 4TB.
} 
quantities of fishmeal. Similar responses have recently been reported by Pell et al. (1989) who examined the use of growth hormone in lambs receiving three levels of protein in the diet at two levels of energy intake.

The present study was undertaken in part to explain the mechanisms responsible for the response observed by Gill et al. (1987). Thus, growing cattle were offered grass silage alone, or with fishmeal supplementation, the latter treatment being offered to both oestradiolimplanted and non-implanted animals. A fourth treatment was included which examined the mode of action of a $\beta$-adrenergic agonist which had been shown in previous studies to increase the protein:fat ratio in the carcass (for example, Kim et al. 1987).

Preliminary results of the present study have been reported previously (Dawson et al. 1987).

\section{MATERIALS AND METHODS}

\section{Animals and treatments}

Thirty 13-week-old Friesian steers with an average initial live weight (LW) of $113 \mathrm{~kg}$ were randomly allocated to one of five groups, each with six animals. One of these groups was allocated for initial slaughter (see p. 173). Of the remaining twenty-four animals, twelve were offered silage alone and twelve were offered the same silage supplemented with fishmeal at $150 \mathrm{~g} / \mathrm{kg}$ silage dry matter (DM). Six of the animals offered fishmealsupplemented silage were also ear-implanted with oestradiol-17 $\beta$ (Compudose 365 ), while six of the animals offered silage alone were administered the $\beta$-agonist cimaterol $(0.06 \mathrm{mg} / \mathrm{kg} \mathrm{LW}$ per d) via osmotic minipumps implanted subcutaneously (Alzet, model 2ML4; Scientific Marketing Associates, London). Three animals in the control (silageonly) group were sham-implanted with minipumps containing buffer alone. These pumps are designed to deliver $2.5 \mu \mathrm{l} / \mathrm{h}$ continuously for 4 weeks. The compatibility of the $\beta$ agonist solution with the pumps was tested in vitro and found to be satisfactory, but in order to ensure a constant delivery of cimaterol the pumps were changed every $24 \mathrm{~d}$ and during the experiment each animal was implanted with a total of three pumps. The $\beta$ agonist solution was prepared under sterile conditions and sterile-filtered before the pumps were filled.

\section{Diets}

The silage was prepared from a primary growth of perennial ryegrass (Lolium perenne var. Frances) harvested on 30 May 1986 after a $24 \mathrm{~h}$ wilting period. Formic acid was added at the time of harvest at the rate of 3.4 litres/tonne fresh grass. The grass was ensiled in a heavy-duty polythene bag (Ag-Bag Corporation, Oregon, USA) with a packing pressure of $5.2 \times 10^{6} \mathrm{~Pa}$ and sealed for $102 \mathrm{~d}$. The silage was well preserved with a high lactic acid content, $106 \mathrm{~g}$ ammonia-nitrogen $/ \mathrm{kg}$ total $\mathrm{N}$ and $\mathrm{pH} 4.0$. A full chemical composition of the silage is given in Table 1.

The silage was removed daily from the clamp as required and fishmeal (Provimi 66; British White Fish Meals Ltd) was thoroughly mixed with the silage by hand at the time of feeding. The fishmeal had an organic matter content of $817 \mathrm{~g} / \mathrm{kg} \mathrm{DM}$ and a $\mathrm{N}$ content of $105 \mathrm{~g} / \mathrm{kg} \mathrm{DM}$. Animals were allowed free access to water and mineral licks were provided at all times.

\section{Experimental procedures}

The animals used in the experiment were obtained as 1-week-old calves in three equal batches $(n 10)$, each separated in age by 2 weeks. All calves received reconstituted milk powder until week 6 , when they were weaned and maintained on a hay-concentrate diet fed ad lib. At 12 weeks of age, silage was introduced to all animals and the diet change-over 
Table 1. Chemical composition of the silage $(\mathrm{g} / \mathrm{kg} \mathrm{DM})$

\begin{tabular}{ll} 
Toluene $\mathrm{DM}^{*}(\mathrm{~g} / \mathrm{kg}$ fresh) & 244 \\
Lactic acid & $154 \cdot 3$ \\
Acetic acid & $12 \cdot 2$ \\
Propionic acid & $0 \cdot 24$ \\
Iso-butyric acid & $0 \cdot 36$ \\
$n$-Butyric acid & $0 \cdot 45$ \\
Total nitrogen & $26 \cdot 1$ \\
Ammonia-N (g/kg total N) & $105 \cdot 7$ \\
Gross energy (MJ/kg DM) & $17 \cdot 7$ \\
pH & $4 \cdot 0$ \\
\hline
\end{tabular}

DM, dry matter.

* Corrected for ethanol content.

was completed within $10 \mathrm{~d}$. At this stage, two animals from each batch were assigned to either one of the four treatment groups or to the initial slaughter group, the latter being slaughtered immediately, with dissection of three muscles (longissimus dorsi, vastus lateralis and semitendinosus) from the left side of the carcass, which were weighed and stored at $-20^{\circ}$. These values were used to create a regression of LW $v$. muscle weight in order to estimate the initial muscle weights of the animals in the other four treatment groups. In order to increase the accuracy of this regression, a further six animals of similar age and identical nutritional history but with a greater LW range $(80-135 \mathrm{~kg})$ were later slaughtered and the muscle weight and body-weight values combined with those of the initial six animals.

The remaining eight animals from each batch were penned in two groups of four by diet (silage or silage plus fishmeal) for the first 7 weeks of treatment. They were offered the diets ad lib. once daily at 08.30 hours with feed offered in amounts $10-15 \%$ in excess of the previous days consumption. Refused food was removed daily and weighed.

At 20 weeks of age, one animal from each treatment group was transferred to an individual pen for 2 weeks and fed ad lib. but with feed offered in two equal portions at 09.00 and 17.00 hours. At 21 weeks of age the other animal from each treatment group was also transferred to an individual pen for 2 weeks. During these times estimates of food intake by each animal were obtained, whilst animal LW was recorded weekly throughout the whole experimental period (9-10 weeks).

At 22 or 23 weeks of age, animals were transferred to metabolism crates and fed hourly from automatic belt feeders. After $2 \mathrm{~d}$ adaptation, urine was collected each day for $4 \mathrm{~d}$. The urine was collected by gravity and immediately pumped into plastic vessels containing $5 \mathrm{M}$-sulphuric acid. The total volume was measured each day and a subsample stored at $-20^{\circ}$.

Immediately following the urine collection, fractional synthetic rates (FSR) of muscle protein were determined by the constant infusion method of Garlick et al. (1973). Sterile polyurethane catheters $(1.2 \mathrm{~mm}$ internal diameter) with Secalon universal Floswitches (Viggo Products, Swindon) were inserted into each jugular vein and secured with a stitch. The left infusion catheter and the right sampling catheter were 300 and $200 \mathrm{~mm}$ long respectively. The catheters were kept patent with sterile saline $(9 \mathrm{~g}$ sodium chloride/l) containing $37.5 \mathrm{IU}$ heparin $/ \mathrm{ml}$.

The following day, each animal was infused with $148 \mathrm{MBq} \mathrm{L}$-[side chain $2,3-{ }^{3} \mathrm{H}$ ] tyrosine $(1.78 \mathrm{TBq} / \mathrm{mmol}$; Amersham International, Amersham, Bucks.) in $300 \mathrm{ml}$ sterile saline containing 0.05 mM-tyrosine (final specific radioactivity (SRA) $9.20 \mathrm{MBq} / \mu \mathrm{mol}$ ) over a 
$6 \mathrm{~h}$ period (about $0.75 \mathrm{ml} / \mathrm{min}$ ) by peristaltic pump (Minipuls 2; Gilson, France), the actual quantity infused being measured accurately for each animal. Blood samples $(20 \mathrm{ml})$ were taken immediately before the start of the infusion and at $30 \mathrm{~min}$ intervals thereafter. Plasma was immediately isolated by centrifuging at $1000 \mathrm{~g}$ for $15 \mathrm{~min}$ and was stored frozen at $-20^{\circ}$ until analysed for plasma free tyrosine SRA. After $6 \mathrm{~h}$, but while the infusion continued, each animal was given a lethal dose of pentobarbitone (Euthanasia; Univet 2 Ltd, Bicester, Oxon) via the contralateral catheter and exsanguinated. The infusion was terminated and samples (approximately $15 \mathrm{~g}$ ) of the 1 . dorsi, v. lateralis and semitendinosus muscles were rapidly $(<2 \mathrm{~min})$ excised from the right side of the carcass and frozen in liquid $\mathrm{N}_{2}$. For consistency, samples from the 1 . dorsi were always taken from the mid-region of the muscle, approximately equidistant from the shoulder and tail. The entire muscles were then dissected from the opposite side of the carcass, weighed and stored at $-20^{\circ}$ for subsequent analysis.

\section{Sample preparation and analysis}

Diets. Samples of silage were taken daily throughout the experiment, pooled on a weekly basis and subsampled. Silage analyses were determined as described by Gill et al. (1987).

Tissues. Muscles were trimmed of any surface fat and extrinsic connective tissue, diced and minced through a $5 \mathrm{~mm}$ mincing plate. The mince was mixed and re-minced twice to ensure homogeneity. Subsamples $(200-400 \mathrm{~g})$ of mince from each muscle were re-frozen and freeze-dried to constant weight. The dried material was finely ground in a laboratory mill and stored dessicated until analysed for $\mathrm{N}$, fat and ash content. Moisture absorbed during grinding was corrected for by oven-drying some of the ground material at $105^{\circ}$ for $16 \mathrm{~h}$.

$\mathrm{N}$ content was determined by the conventional Kjeldahl method. Total intramuscular fat content was determined by the Weibul method whereby conjugated and occluded lipid is released by acid-hydrolysis ( 3 M-hydrochloric acid, 1 h) before Soxhlet extraction with light petroleum (40-60 b.p.) (Osborne \& Voogt, 1978). Ash content was determined after ovendrying the ground sample at $100^{\circ}$ for $4 \mathrm{~h}$, followed by $550^{\circ}$ for $16 \mathrm{~h}$.

The fatty acid composition of the intramuscular lipid of the 1 . dorsi muscle was determined by gas-liquid chromatography after solvent extraction of the lipid by the method of Folch et al. (1957). Portions of extracted lipid ( $3-5 \mathrm{mg}$ in chloroform) were applied to a column $(10 \mathrm{~mm} \times 80 \mathrm{~mm})$ of silicic acid (Sigma Chemical Co, Poole, Dorset) and eluted with $25 \mathrm{ml}$ chloroform followed by $25 \mathrm{ml}$ methanol to fractionate the lipid into triacylglycerol and phospholipid components respectively. Both eluant fractions were dried by rotary evaporation and then methylated by incubating in $1 \mathrm{M}-\mathrm{H}_{2} \mathrm{SO}_{4}$ in methanol $(5 \mathrm{ml})$ at $70^{\circ}$ for $135 \mathrm{~min}$. The fatty acid methyl esters (FAME) were extracted with light petroleum (twice with $2 \mathrm{ml}$ ), washed with saturated sodium carbonate, dried, dissolved in iso-octane and analysed on a $10 \%$ Silar 10C column (100-120 mesh Gas Chrom Q). The $\mathrm{C}_{14 \cdot 0}, \mathrm{C}_{16 \cdot 0}, \mathrm{C}_{16 \cdot 1}, \mathrm{C}_{18 \cdot 0}, \mathrm{C}_{18 \cdot 1}, \mathrm{C}_{18 \cdot 2}, \mathrm{C}_{18 \cdot 3}, \mathrm{C}_{20.0}, \mathrm{C}_{20 \cdot 4}, \mathrm{C}_{22 \cdot 6}$ FAME of the triacylglycerol and phospholipid fractions were identified and quantified using calibration factors calculated from quantitative standards. The $\mathrm{C}_{15.0}, \mathrm{C}_{17.0}, \mathrm{C}_{18}$ branched, $\mathrm{C}_{20.3}, \mathrm{C}_{20.5}$ and $\mathrm{C}_{22.5} \mathrm{FAME}$ were identified from a graph of the logarithm of the retention time $v$. equivalent chain length (Christie, 1973). These sixteen FAME accounted for $>90 \%$ of the total peak areas in the samples.

Urine. Urinary $N^{r}$-methylhistidine content was determined by amino acid analysis with lithium citrate buffers (Atkin \& Ferdinand, 1970) after desalting the urine by eluting through a column $(150-200 \mathrm{~mm})$ of Dowex $50 \mathrm{~W}-\mathrm{X} 8\left(100-200\right.$ mesh; $\mathrm{H}^{+}$form) with $4 \mathrm{M}-$ ammonium hydroxide followed by rotary evaporation and thorough washing. Creatinine content was determined colorimetrically using the Jaffe reaction (Owen et al. 1954). 
Table 2. Effect of cimaterol, fishmeal and oestradiol on growth rates and individual muscle weights of silage-fed steers

\begin{tabular}{|c|c|c|c|c|c|}
\hline Treatment group $\nmid \ldots$ & Silage & Cimaterol & Fishmeal & $\begin{array}{l}\text { Fishmeal } \\
\text { +oestradiol }\end{array}$ & $\begin{array}{l}\text { Pooled SED } \\
\text { (df 18) }\end{array}$ \\
\hline $\begin{array}{l}\text { Live weight (LW) } \\
\text { gain }(\mathrm{g} / \mathrm{d})\end{array}$ & 416 & 366 & $865^{* * *}$ & $1146^{* * *}$ & $71 \cdot 1$ \\
\hline \multicolumn{6}{|l|}{ Longissimus dorsi } \\
\hline $\mathrm{kg}$ & 1.217 & $1.494^{*}$ & {$[.69]^{* * *}$} & $1 \cdot 960^{* * *}$ & $0 \cdot 120$ \\
\hline $\mathrm{g} / \mathrm{kg} \mathrm{LW}$ & 8.745 & $10 \cdot 732 * *$ & $10 \cdot 024^{*}$ & $10 \cdot 225^{*}$ & 0.558 \\
\hline \multicolumn{6}{|l|}{ Vastus lateralis } \\
\hline $\mathrm{kg}$ & 0.514 & $0.642^{* * *}$ & $0.696^{* * *}$ & $0.762^{* * *}$ & 0.041 \\
\hline $\mathrm{g} / \mathrm{kg} \mathrm{LW}$ & 3.692 & $4 \cdot 597^{* * *}$ & $4 \cdot 130^{*}$ & 3.981 & 0.181 \\
\hline \multicolumn{6}{|l|}{ Semitendinosus } \\
\hline $\mathrm{kg}$ & 0.475 & 0.504 & $0.651^{* * *}$ & $0.735^{* * *}$ & 0.044 \\
\hline $\mathrm{g} / \mathrm{kg} \mathrm{LW}$ & 3.419 & 3.608 & $3 \cdot 856^{* *}$ & $3 \cdot 829 *$ & 0.151 \\
\hline
\end{tabular}

SED, standard error of the difference between means.

Mean values were significantly different from those of silage-fed controls: ${ }^{*} P<0.05,{ }^{* *} P<0.01$, $* * * P<0.001$

$\dagger$ For details of treatments, see pp. 172173.

Determination of tyrosine SRA. Plasma-free tyrosine SRA and the protein-bound and free tyrosine SRA in the snap-frozen muscle samples were determined in duplicate as described by Garlick \& Marshall (1972) and Garlick et al. (1973). L-Tyrosine decarboxylase (EC 4.1.1.25; Sigma Chemical Co, Poole, Dorset) was used for the enzymic conversion of tyrosine to tyramine. The concentration of tyramine was measured fluorimetrically by the nitro-naphthol method of Waalkes \& Udenfriend (1957) and radioactivity was determined by liquid scintillation counting.

\section{Calculation of results}

Initial muscle weights of animals in the four treatment groups were estimated from regressions of LW $v$. muscle weight obtained from the twelve animals which comprised the initial slaughter group.

The regression equations for the initial muscle weights $(y)$ were:

$$
\begin{aligned}
\text { longissimus dorsi : } y & =0.00488 \times \text { initial liveweight }-0.12098 \\
\text { vastus lateralis : } y & =0.00445 \times \text { initial liveweight }-0.01696 \\
\text { semitendinosus : } y & =0.01696 \times \text { initial liveweight }-0.78001
\end{aligned}
$$

Initial protein contents of these muscles were calculated using the $\mathrm{N}$ and $\mathrm{DM}$ determinations made on the muscles dissected from the initial slaughter group.

The fractional protein gain (FPG) of the individual muscles was estimated from the increase in muscle protein content over the treatment period:

$$
\mathrm{FPG}=\frac{\text { final protein content }- \text { initial protein content }}{\text { median protein content }} \times \frac{100}{\text { days of treatment }}
$$

Median protein contents were calculated as the mean of the initial and final protein contents.

Muscle protein FSR were calculated from the plasma free- and the homogenate freetyrosine pools using the basic equation of Garlick et al. (1973) as described by Lobley et al. (1980). Plasma free FSR were measured in all the samples taken throughout the 
infusion and an average value was determined for each steer from the samples taken during the final $3.5 \mathrm{~h}$ of the infusion when the plateau value $\left(S_{\mathrm{p}-\max }\right)$ was reached $(n 8)$. Rate constants $(\phi)$ describing the increase in plasma SRA during infusion were determined by fitting the data from each steer to the following equation:

$$
S=S_{\mathrm{p}-\max }\left(1-e^{\phi t}\right)
$$

where $S$ is SRA of plasma free tyrosine, $S_{\mathrm{p}-\max }$ is value of $S$ at plateau, $\phi$ is the rateconstant, $t$ is time.

An average value for $\phi$ of $66.5 / \mathrm{d}$ was obtained which was used in the calculation of FSR for all steers. This value was assumed to be the same for the tissues (Nicholas et al. 1977) and so was used in the calculation of FSR from both the precursor pools (Lobley et al. 1980). Values for FSR based on plasma were assumed to give a minimum estimate of protein synthetic rate, while those based on the homogenate (intracellular) pool were assumed to give an upper estimate (Eisemann et al. 1989). Absolute rates of protein synthesis $(\mathrm{g} / \mathrm{d})$ were estimated from the FSR and the final muscle protein content.

\section{Statistical analysis}

The effect of treatment was examined by analysis of variance with treatment and batch as main effects. Growth rates were determined for each animal by linear regression over 910 weeks and the slopes tested by analysis of variance. Differences between the groups were assumed to be not significantly different at $P>0 \cdot 10$.

\section{RESULTS}

Animal performance and muscle composition

Animal growth rates and weights of the three individual muscles obtained at slaughter are shown in Table 2 . Animals administered the $\beta$-agonist cimaterol showed similar rates of LW gain to control (silage only) animals (approximately $0.4 \mathrm{~kg} / \mathrm{d}$ ) but their 1 . dorsi and v. lateralis muscle weights were significantly increased $(P<0 \cdot 05)$. The semitendinosus muscle, however, showed no myogenic response to cimaterol.

Animals fed on fishmeal-supplemented silage showed a significantly higher growth rate $(0.87 \mathrm{~kg} / \mathrm{d})$ compared with those fed on silage alone $(P<0.001)$, and this was further increased to $1.15 \mathrm{~kg} / \mathrm{d}$ by oestradiol, resulting in a significant effect of oestradiol on growth over non-implanted animals receiving fishmeal $(P<0 \cdot 01)$. All muscle weights of both oestradiol-implanted and non-implanted fishmeal animals were significantly increased relative to those of the silage-only controls, both in absolute terms $(\mathrm{kg})$ and when expressed as a proportion of body-weight. L. dorsi and semitendinosus muscle weights were significantly heavier in oestradiol animals than in non-implanted fishmeal-supplemented animals $(P<0 \cdot 10)$ but were similar when expressed relative to body-weight.

The contents of DM, crude protein $(\mathrm{N} \times 6.25)$, fat and ash of the three muscles are given in Table 3. Cimaterol significantly reduced the DM content of the semitendinosus muscle $(P<0.01)$ compared with the controls and showed a similar tendency in the 1 . dorsi, although this was not significant. However, the proportion of protein in the DM was significantly increased $(P<0.001)$ and the lipid content was significantly reduced $(P<$ $0.05)$ in all three muscles by cimaterol. Fishmeal and fishmeal-plus-oestradiol treatments significantly $(P<0.01)$ increased the DM content of the $\mathrm{v}$. lateralis compared with the silage-only fed cattle and showed similar tendencies in the other two muscles, but had no apparent effects on the proportion of protein, lipid or ash in any of the muscles, except for an increase in ash content in the 1 . dorsi muscle of non-implanted fishmeal animals $(P<0 \cdot 05)$. 
Table 3. Effect of cimaterol, fishmeal and oestradiol on muscle dry matter contents of young steers

\begin{tabular}{|c|c|c|c|c|c|}
\hline Treatment group $+\ldots$ & Silage & Cimaterol & Fishmeal & $\begin{array}{l}\text { Fishmeal } \\
\text { + oestradiol }\end{array}$ & $\begin{array}{l}\text { Pooled SED } \\
\qquad(\mathrm{d} f \mathbf{1 8})\end{array}$ \\
\hline \multicolumn{6}{|l|}{ Longissimus dorsi } \\
\hline Dry matter ( $\mathrm{g} / \mathrm{kg}$ muscle $)$ & $247 \cdot 8$ & $238 \cdot 5$ & 253.0 & 253.6 & $7 \cdot 21$ \\
\hline Protein $\S(\mathrm{g} / \mathrm{kg} \mathrm{DM})$ & $889 \cdot 0$ & $932 \cdot 7^{* * *}$ & $881 \cdot 2$ & $884 \cdot 9$ & $8 \cdot 21$ \\
\hline Lipid (g/kg DM) & 53.6 & $38 \cdot 1^{*}$ & $55 \cdot 6$ & $54 \cdot 0$ & $6 \cdot 08$ \\
\hline Ash $(\mathrm{g} / \mathrm{kg} \mathrm{DM})$ & $52 \cdot 1$ & 54.8 & $58 \cdot 8^{*}$ & $51 \cdot 4$ & $2 \cdot 46$ \\
\hline \multicolumn{6}{|l|}{ Vastus lateralis } \\
\hline Dry matter (g/kg muscle) & $229 \cdot 2$ & $227 \cdot 0$ & $239 \cdot 0^{* *}$ & $237 \cdot 4 * *$ & $2 \cdot 58$ \\
\hline Protein $\S(\mathrm{g} / \mathrm{kg} \mathrm{DM})$ & $878 \cdot 8$ & $926 \cdot 5^{* * *}$ & 873.4 & $883 \cdot 0$ & $6 \cdot 70$ \\
\hline Lipid (g/kg DM) & $54 \cdot 0$ & $34 \cdot 5 * *$ & $51 \cdot 8$ & $50 \cdot 4$ & $5 \cdot 90$ \\
\hline Ash $(\mathrm{g} / \mathrm{kg} \mathrm{DM})$ & $61 \cdot 4$ & $56 \cdot 7$ & $56 \cdot 9$ & $64 \cdot 6$ & $5 \cdot 33$ \\
\hline \multicolumn{6}{|l|}{ Semitendinosus } \\
\hline Dry matter $(\mathrm{g} / \mathrm{kg}$ muscle $)$ & 243.8 & $230 \cdot 0^{* *}$ & $250 \cdot 4$ & $252 \cdot 5 \uparrow$ & 4.59 \\
\hline Protein $\S(\mathrm{g} / \mathrm{kg} \mathrm{DM})$ & $872 \cdot 1$ & $928 \cdot 3 * * *$ & $873 \cdot 6$ & $864 \cdot 8$ & $10 \cdot 1$ \\
\hline Lipid (g/kg DM) & 700 & $33 \cdot 8^{* *}$ & $63 \cdot 0$ & $74 \cdot 4$ & $11 \cdot 6$ \\
\hline Ash $(\mathrm{g} / \mathrm{kg} \mathrm{DM})$ & $52 \cdot 7$ & $55 \cdot 8$ & $53 \cdot 9$ & $53 \cdot 3$ & 3.09 \\
\hline
\end{tabular}

SED, standard error of the difference between means.

Mean values were significantly different from those of silage-fed controls: $\dagger P<0 \cdot 10,{ }^{*} P<0 \cdot 05,{ }^{*} P<0 \cdot 01$, $* * * P<0.001$.

$\ddagger$ For details of treatments, see pp. 172-173.

$\S$ Nitrogen $\times 6.25$.

\section{Muscle protein synthesis rates}

Muscle protein FSR were determined using both the plasma free- ( $\mathrm{K}_{\mathrm{s}}$-plasma) and the homogenate free-tyrosine pool $\left(\mathrm{K}_{\mathrm{s}}\right.$-hom) as precursors (Table 4). Similar trends between the four treatment groups were obtained with both precursors but the variability associated with the homogenate-free amino acid determinations tended to be somewhat greater. Cimaterol increased $\mathrm{K}_{\mathrm{s}}$-plasma in the $\mathrm{v}$. lateralis $(P<0.05)$ and $\mathrm{K}_{\mathrm{s}}$-hom in both the v. lateralis $(P<0.05)$ and 1 . dorsi $(P<0.05)$. Fishmeal increased $\mathrm{K}_{\mathrm{s}}$-plasma in all three muscles compared with the silage-only-fed animals but $\mathrm{K}_{\mathrm{s}}$-hom values, although tending to be higher than those of control animals, were not significantly different. Oestradiol treatment also significantly increased $\mathrm{K}_{\mathrm{s}}$-plasma in all three muscles compared with silageonly-fed animals and $\mathrm{K}_{\mathrm{s}}$-hom was significantly increased in the $\mathrm{v}$. lateralis $(P<0.01)$. No significant differences in FSR between implanted and non-implanted fishmeal animals were obtained in any of the muscles.

Absolute rates $(\mathrm{g} / \mathrm{d})$ of muscle protein synthesis ( $\mathrm{A}_{\mathrm{s}}$-plasma and $\mathrm{A}_{\mathrm{s}}$-hom) were significantly increased by cimaterol treatment in 1 . dorsi and $v$. lateralis muscles whether calculated from $\mathrm{K}_{\mathrm{s}}$-plasma or $\mathrm{K}_{\mathrm{s}}$-hom estimates, but the semitendinosus remained unaffected by treatment (Table 4). Fishmeal and fishmeal plus oestradiol increased protein synthesis in all three muscles $(P<0.05)$ compared with those of the silage-fed controls. Animals implanted with oestradiol tended to show slightly greater rates of muscle protein synthesis than non-implanted fishmeal animals but these differences were generally not significant. Tyrosine flux was, however, significantly higher in these animals.

The fractional rate of muscle protein gain was significantly increased by cimaterol in the v. lateralis $(P<0.01)$ with the 1 . dorsi showing a similar but non-significant tendency, but FPG in the semitendinosus muscle was similar to that of the silage-fed controls (Table 5). Both implanted and non-implanted animals given fishmeal showed significant $(P<0.001)$ increases in FPG in all three muscles compared with the controls. Implanted animals 
Table 4. Effect of cimaterol, fishmeal and oestradiol on the protein fractional synthetic rate $(\% / d)$ and absolute rate of protein synthesis $(\mathrm{g} / \mathrm{d})$ in three individual muscles from young steers

\begin{tabular}{|c|c|c|c|c|c|}
\hline Treatment groupt... & Silage & Cimaterol & Fishmeal & $\begin{array}{c}\text { Fishmeal+ } \\
\text { oestradiol }\end{array}$ & $\begin{array}{l}\text { Pooled SED } \\
\text { (df 18) }\end{array}$ \\
\hline \multicolumn{6}{|l|}{ Longissimus dorsi } \\
\hline $\mathrm{K}_{\mathrm{s}}$-plasma & $0 \cdot 85$ & $1 \cdot 09$ & $1 \cdot 30^{*}$ & $1 \cdot 29^{*}$ & $0 \cdot 161$ \\
\hline $\mathrm{K}_{\mathrm{s}}$-hom & $2 \cdot 30$ & $4 \cdot 45^{*}$ & $3 \cdot 44$ & $3 \cdot 51$ & 0.758 \\
\hline$A_{\text {s }}^{3}$-plasma & $2 \cdot 35$ & $3.58 \dagger$ & $4 \cdot 87^{* * *}$ & $5 \cdot 68 * * *$ & 0.639 \\
\hline$A_{s}$-hom & $6 \cdot 27$ & $14 \cdot 19^{* *}$ & $12 \cdot 92^{*}$ & $15 \cdot 01^{* *}$ & $2 \cdot 37$ \\
\hline \multicolumn{6}{|l|}{ Vastus lateralis } \\
\hline $\mathrm{K}_{4}$-plasma & 0.82 & $1 \cdot 18^{*}$ & $1 \cdot 19^{*}$ & $1 \cdot 39 * *$ & $0 \cdot 152$ \\
\hline $\mathrm{K}_{\mathrm{s}}$-hom & $2 \cdot 53$ & $3.76^{*}$ & 3.42 & $4 \cdot 19^{* *}$ & 0.576 \\
\hline$A_{s}$-plasma & 0.88 & $1.61 * *$ & $1.72^{* *}$ & $2 \cdot 22 * * *$ & $0 \cdot 234$ \\
\hline$A_{s}$-hom & $2 \cdot 67$ & $5.09^{*}$ & $4.98^{*}$ & $6 \cdot 74 * * *$ & 0.944 \\
\hline \multicolumn{6}{|l|}{ Semitendinosus } \\
\hline $\mathrm{K}_{\mathrm{s}}$-plasma & $0 \cdot 71$ & 0.84 & $1.05^{*}$ & $1 \cdot 08^{*}$ & $0 \cdot 161$ \\
\hline $\mathrm{K}_{\mathrm{s}}$-hom & $2 \cdot 74$ & $2 \cdot 85$ & 3.43 & 3.01 & 0.599 \\
\hline$A_{s}^{s}$-plasma & $0 \cdot 74$ & 0.89 & $1 \cdot 52^{*}$ & $1 \cdot 73^{* *}$ & $0 \cdot 261$ \\
\hline$A_{s}^{s}$-hom & $2 \cdot 96$ & 3.03 & $5 \cdot 01^{*}$ & $4 \cdot 75 \dagger$ & 0.902 \\
\hline Tyrosine flux $\S \mathrm{mmol} / \mathrm{h}$ & $7 \cdot 62$ & 7.96 & $10 \cdot 74 * * *$ & $13 \cdot 33^{* * *}$ & 0.67 \\
\hline
\end{tabular}

SED, standard error of difference between means; $\mathrm{K}_{\mathrm{s}}$-plasma, $\mathrm{K}_{\mathrm{s}}$-hom, fractional synthetic rates determined from the plasma free- and the intracellular free-tyrosine pools respectively using the equation of Garlick ef al. (1973) with a rate-constant $(\phi)$ of $66.5 / \mathrm{d}$; A -plasma, $A_{s}$-hom, absolute rates of muscle protein synthesis calculated from $K_{s}$-plasma or $K_{s}$-hom respectively, and the final protein content of the muscles.

Mean values were significantly different from those of silage-fed controls: $\dagger P<0 \cdot 10,{ }^{*} P<0 \cdot 05,{ }^{* *} P<0.01$, *** $P<0.001$.

$\ddagger$ For details of treatments, see pp. 172 173 .

$\S$ Tyrosine flux was calculated from the infusion rate of $\left[{ }^{3} \mathrm{H}\right]$ tyrosine and the specific radioactivity of the plasma pool at plateau.

Table 5. Effect of cimaterol, fishmeal and oestradiol on fractional protein gain $\dagger(\% / d)$ in three individual muscles

\begin{tabular}{llllll}
\hline Treatment group $\neq \ldots$ & Silage & Cimaterol & Fishmeal & $\begin{array}{c}\text { Fishmeal } \\
\text { +oestradiol }\end{array}$ & $\begin{array}{c}\text { Pooled SED } \\
\text { (df 18) }\end{array}$ \\
\hline \hline Longissimus dorsi & 0.248 & 0.389 & $0.721^{* *}$ & $0.824^{* * *}$ & 0.122 \\
Vastus lateralis & 0.192 & $0.494^{* *}$ & $0.681^{* * *}$ & $0.753^{* * *}$ & 0.088 \\
Semitendinosus & 0.208 & 0.193 & $0.712^{* * *}$ & $0.795^{* * *}$ & 0.080 \\
\hline
\end{tabular}

$\dagger$ Estimated from the increase in muscle protein content over the treatment period (see p. 175). Average median protein contents of the longissimus dorsi; vastus lateralis and semitendinosus muscles in the 4 treatment groups were: silage, 249.5, 97.9, 94.8; cimaterol, 295.1, 116.5, 101·3; fishmeal, 305.7, 119.1, 115.7; fishmeal plus oestradiol, $348 \cdot 3,128 \cdot 7,127 \cdot 5 \mathrm{~g}$ respectively.

SED, standard error of the difference between means,

Mean values were significantly different from those of silage-fed controls: ${ }^{* *} P<0.01,{ }^{* * *} P<0.001$.

$\$$ For details of treatments, see pp. 172-173.

tended to deposit more protein than the non-implanted animals, but these differences were not significant.

An index of whole-body skeletal muscle degradation obtained from the urinary $N^{r}$-methylhistidine:creatinine ratio indicated a significant reduction in cimaterol-treated animals compared with silage-only-fed cattle $(16.9 \mathrm{mg} / \mathrm{g}$ compared with $21.7 \mathrm{mg} / \mathrm{g}$; 
Table 6. Effect of cimaterol, fishmeal and oestradiol on the fatty acid composition of the longissimus dorsi triacylglycerol fraction ( $\%$ mass composition)

\begin{tabular}{|c|c|c|c|c|c|}
\hline Treatment group $† . .$. & Silage & Cimaterol & Fishmeal & $\begin{array}{l}\text { Fishmeal } \\
+ \text { oestradiol }\end{array}$ & $\begin{array}{l}\text { Pooled SED } \\
\text { (df 18) }\end{array}$ \\
\hline \multicolumn{6}{|l|}{ Fatty acid } \\
\hline 140 & $2 \cdot 76$ & $2 \cdot 77$ & $3 \cdot 28$ & $2 \cdot 88$ & $0 \cdot 24$ \\
\hline 150 & 1.63 & $2 \cdot 47$ & 201 & $1 \cdot 74$ & 0.42 \\
\hline 160 & $25 \cdot 33$ & $22 \cdot 76^{*}$ & $26 \cdot 45$ & $24 \cdot 76$ & 0.99 \\
\hline $16 \cdot 1$ & 3.73 & 3.67 & 3.79 & 3.66 & $0 \cdot 22$ \\
\hline $17 \cdot 0$ & 1.75 & $2 \cdot 22$ & $2 \cdot 07$ & 2.03 & $0 \cdot 21$ \\
\hline 18 branched & 0.83 & 0.87 & 0.78 & 0.75 & 0.07 \\
\hline $18 \cdot 0$ & $20 \cdot 75$ & $24 \cdot 57^{* *}$ & $21 \cdot 59$ & $23 \cdot 31^{*}$ & $1 \cdot 17$ \\
\hline $18 \cdot 1$ & 33.91 & $32 \cdot 33^{*}$ & $32 \cdot 14^{*}$ & $31.88^{*}$ & 0.73 \\
\hline $18 \cdot 2$ & $2 \cdot 47$ & $2 \cdot 46$ & $2 \cdot 23$ & $2 \cdot 47$ & $0 \cdot 23$ \\
\hline $20 \cdot 0$ & $0 \cdot 19$ & $0 \cdot 2 !$ & $0.41^{* *}$ & $0.37^{*}$ & 0.07 \\
\hline $18 \cdot 3$ & $1 \cdot 29$ & $1 \cdot 38$ & $1.61 *$ & $1.91 * * *$ & $0 \cdot 14$ \\
\hline
\end{tabular}

SED, standard error of the difference between means.

Mean values were significantly different from those of silage-fed controls: ${ }^{*} P<0 \cdot 05,{ }^{*} P<0 \cdot 01$, *** $P<0.001$.

+ For details of treatments, see pp. 172-173.

Table 7. Effect of cimaterol, fishmeal and oestradiol on the fatty acid composition of the longissimus dorsi phospholipid fraction ( $\%$ mass composition)

\begin{tabular}{|c|c|c|c|c|c|}
\hline Treatment group $\dagger . .$. & Silage & Cimaterol & Fishmeal & $\begin{array}{c}\text { Fishmeal } \\
+ \text { oestradiol }\end{array}$ & $\begin{array}{l}\text { Pooled SED } \\
\text { (df 18) }\end{array}$ \\
\hline \multicolumn{6}{|l|}{ Fatty acid } \\
\hline 140 & $0 \cdot 90$ & $0 \cdot 81$ & 0.92 & $0 \cdot 83$ & $0 \cdot 22$ \\
\hline $15 \cdot 0$ & $4 \cdot 05$ & 3.29 & $3 \cdot 23$ & $3 \cdot 21$ & $0 \cdot 71$ \\
\hline $16 \cdot 0$ & $14 \cdot 24$ & $16 \cdot 31$ & 15.90 & $15 \cdot 39$ & 0.79 \\
\hline $16 \cdot 1$ & $2 \cdot 68$ & $3 \cdot 02$ & $2 \cdot 78$ & $2 \cdot 83$ & $0 \cdot 29$ \\
\hline $17 \cdot 0$ & 2.69 & $2 \cdot 11$ & $2 \cdot 40$ & $2 \cdot 40$ & $0 \cdot 32$ \\
\hline 18 branched & $2 \cdot 05$ & $2 \cdot 03$ & 1.92 & 2.07 & $0 \cdot 13$ \\
\hline $18 \cdot 0$ & $12 \cdot 54$ & $13 \cdot 80$ & $12 \cdot 60$ & $12 \cdot 24$ & 0.82 \\
\hline $18 \cdot 1$ & $27 \cdot 14$ & $26 \cdot 61$ & $23 \cdot 47^{*}$ & $23 \cdot 39 *$ & $1 \cdot 41$ \\
\hline $18 \cdot 2$ & $8 \cdot 79$ & $7 \cdot 91$ & $8 \cdot 15$ & $8 \cdot 62$ & 0.63 \\
\hline $18 \cdot 3$ & $2 \cdot 03$ & $2 \cdot 14$ & $2 \cdot 66 * * *$ & $2 \cdot 77^{* * *}$ & $0 \cdot 15$ \\
\hline $20 \cdot 3$ & $1 \cdot 35$ & 1.59 & $0.85^{*}$ & $1 \cdot 04$ & 0.23 \\
\hline $20 \cdot 4$ & 6.63 & $5 \cdot 94$ & $4 \cdot 79^{* *}$ & $4 \cdot 75^{* *}$ & 0.55 \\
\hline $20 \cdot 5$ & 2.99 & $2 \cdot 78$ & $4 \cdot 13^{* * *}$ & $4 \cdot 54 * * *$ & $0 \cdot 28$ \\
\hline $22 \cdot 5$ & $4 \cdot 15$ & 3.75 & $4 \cdot 17$ & $4 \cdot 22$ & $0 \cdot 38$ \\
\hline $22 \cdot 6$ & $1 \cdot 10$ & $1 \cdot 35$ & $4 \cdot 45^{* * *}$ & $4 \cdot 54 * * *$ & 0.27 \\
\hline
\end{tabular}

SED, standard error of the difference between means.

Mean values were significantly different from those of silage-fed controls: ${ }^{*} P<0.05,{ }^{* *} P<0.01$, *** $P<0.001$

$\dagger$ For details of treatments, see pp. 172-173. 
$P<0 \cdot 05$ ). This technique could not be applied to animals fed on fishmeal because fishmeal contains $N^{\top}$-methylhistidine.

\section{Intramuscular lipid composition}

The fatty acid composition of the triacylglycerol and phospholipid fractions of the intramuscular lipid extracted from the 1 . dorsi muscle of animals in the four treatment groups are shown in Tables 6 and 7. Muscle triacylglycerol fatty acids ranged in length from 14 to $20 \mathrm{C}$ atoms with more than $90 \%$ of the peak area being occupied by even-numbered fatty acids. There was a greater proportion of saturated than unsaturated fatty acids in this fraction in all treatment groups. In contrast, the phospholipid fraction contained a greater proportion of unsaturated fatty acids, particularly those of longer chain length. Cimaterol had no effect on muscle phospholipid composition but significantly $(P<0-05)$ reduced the proportion of triacylglycerol $C_{16.0}$ and $C_{18.1}$ fatty acids and increased the proportion of $\mathrm{C}_{18 \cdot 0}$. Fishmeal reduced the proportion of $\mathrm{C}_{18.1}$ and increased the proportions of $\mathrm{C}_{20.0}$ and $\mathrm{C}_{18 \cdot 3}$ in the triacylglycerol fraction. In the phospholipid fraction, $\mathrm{C}_{18 \cdot 1}, \mathrm{C}_{20.3}$ and $\mathrm{C}_{20 \cdot 4}$ were reduced while $\mathrm{C}_{18 \cdot 3}, \mathrm{C}_{20.5}$ and $\mathrm{C}_{22.6}$ were increased. Animals implanted with oestradiol showed similar fatty acid compositions to non-implanted fishmeal animals but triacylglycerol $\mathrm{C}_{18 \cdot 0}$ and $\mathrm{C}_{18 \cdot 3}$ proportions were greater.

\section{DISCUSSION}

Growth response

Supplementation of silage with fishmeal significantly improved the growth rate of young steers and this was further enhanced by oestradiol, although the magnitude of the response to fishmeal in the present experiment was greater than that observed by Gill et al. (1987) with the same level of fishmeal and similar animals. This presumably reflects the poorerquality silage used in the present experiment as shown by the lower growth rates of the control animals $(0.42 \mathrm{~kg} / \mathrm{d}$ compared with $0.77 \mathrm{~kg} / \mathrm{d}$ of Gill et al. 1987). Whilst animals were offered feed ad lib. they were group-fed and, hence, no average measure of food intake over the whole experiment could be made. However, intakes were measured over a short period whilst the animals were housed in individual pens and metabolism crates, and average values of $25 \mathrm{~g} \mathrm{DM} / \mathrm{kg} \mathrm{LW}$ per $\mathrm{d}$ for both control and fishmeal-supplemented diets were recorded. In the experiment of Gill et al. (1987) voluntary food intakes were also unaffected by treatment, with a mean value of $24 \mathrm{~g} \mathrm{DM} / \mathrm{kg} \mathrm{LW}$ per d being obtained for the control and fishmeal-containing diets. It is somewhat surprising that the intakes in the present experiment were at least similar to those obtained by Gill et al. (1987) with a silage of higher quality and we have no explanation for this. Animals implanted with oestradiol appeared to have even higher feed intakes $(26.5 \mathrm{~g} \mathrm{DM} / \mathrm{kg} \mathrm{LW}$ per d), whilst cimateroltreated animals appeared to consume slightly less $(22.8 \mathrm{~g} / \mathrm{kg} \mathrm{LW}$ per d). Other reports have indicated that anabolic agents enhance voluntary feed intake (e.g. Sinnett-Smith et al. 1983) while $\beta$-agonists can reduce intake, especially in pigs (Moser et al. 1986).

The response to fishmeal observed in both the present experiment and that of Gill et al. (1987) suggests that the growth of young steers on silage-only diets is limited by protein supply. Supplementation of silage with fishmeal has been shown to increase amino acid flow to the duodenum (Dawson et al. 1988; Beever et al. 1990) and to increase protein gain in the empty body and carcass (Gill et al. 1987). In the present experiment, the three individual muscles of animals given fishmeal-supplemented silage comprised a significantly greater proportion of body-weight than those of the silage-only controls, indicating that fishmeal preferentially increased lean deposition. The DM content of these muscles tended to be increased but the proportions of protein, lipid and ash remained constant. The fatty 
acid composition of the intramuscular lipid was, however, altered by fishmeal, especially in the phospholipid fraction where there were significant increases in the proportion of some of the unsaturated long-chain fatty acids. This suggests that some direct incorporation of dietary unsaturated fatty acids had occurred. Jackson et al. (1988) reported similar changes in the fatty acid composition of skeletal muscle from rats fed on a fish-oil supplement.

It is well known that the growth potential of an animal can be increased by use of anabolic agents. However, Gill et al. (1987) demonstrated a clear interaction between dietary protein and the response to oestradiol implantation. Thus, animals offered silage alone or with only a low level of fishmeal supplementation $(50 \mathrm{~g} / \mathrm{kg}$ silage DM) showed no response to implantation, but with higher levels of fishmeal ( 100 or $150 \mathrm{~g} / \mathrm{kg}), \mathrm{LW}$ gain was increased by $15 \%$ in implanted compared with non-implanted animals (Gill et al. 1987). This suggests that the increased growth potential induced by implantation cannot be achieved unless dietary protein levels are adequate. A possible explanation for this, involving the nutritional stimulation of hepatic high-affinity somatotrophic receptors and subsequent stimulation of plasma insulin-like growth factor-l (IGF-1) concentrations, was put forward by Breier et al. $(1988 a, b)$. In the present experiment the effect of oestradiol implantation was only investigated in animals given fishmeal-supplemented silage, with animals showing an increased growth rate of $0.28 \mathrm{~kg} / \mathrm{d}$ due to implantation, with all muscle weights increasing proportionally with body-weight.

$\beta$-agonist treatment had no effect on growth rate but had a marked repartitioning effect on the carcass, increasing muscle protein and reducing muscle lipid content. Full carcass analysis was not conducted on these animals, but from visual inspection a reduction in overall carcass fat was quite apparent. Similar effects have been reported in both sheep and cattle by many other workers (Ricks et al. 1984; Bohorov et al. 1987; Williams et al. 1987; Miller et al. 1988). All muscles, however, did not respond identically to the $\beta$-agonist treatment; 1 . dorsi and $\mathrm{v}$. lateralis muscle weights were significantly increased but the semitendinosus muscle weight was apparently unaffected, although its composition was altered in a similar way to the other two muscles. Differences in the response of different muscles to $\beta$-agonist treatment have been reported previously (Beermann et al. 1985; Bohorov et al. 1987; Kim et al. 1988) and have been suggested to reflect differences in fibre type content. Muscle hypertrophy by $\beta$-agonists has been suggested to be associated with an increase in the diameter of type II fibres, type I fibres usually being unaffected or affected to a lesser extent than type II fibres (Kim et al. 1987, 1988; Miller et al. 1988). Muscles from large animals tend not to have such a marked predominance of one particular fibre type as seen in smaller species such as the rat (R. A. Lawrie, personal communication), although the relative proportions of type I and type II fibres in the muscles of animals used in the present study is unknown. Some workers have reported increases of up to $25 \%$ in the weight of the semitendinosus muscles of sheep fed diets containing cimaterol or clenbuterol (Forsberg et al. 1987; Claeys et al. 1989) whilst others have reported increased growth rates with $\beta$-agonist treatment (Quirke et al. 1988; Kim et al. 1987). The reason for this variability in response between studies is unknown, but in all reported cases in which $\beta$-agonists have been administered to livestock species overall carcass yield has been improved. Their mode of action, however, remains uncertain.

It is interesting to note that the FPG in the muscles of the silage-fed animals $(0 \cdot 19-0.25 \% / \mathrm{d}$, Table 5$)$ was less than the fractional gain in body weight $(0 \cdot 33 \% / \mathrm{d})$ while in the other three treatment groups, the FPG (with the exception of the semitendinosus muscle in cimaterol-treated animals) either equalled, or exceeded, the fractional gain in body weight (cimaterol, $0.29 \% / \mathrm{d}$; fishmeal, $0.61 \% / \mathrm{d}$; fishmeal plus oestradiol, $0.76 \% / \mathrm{d}$ ). This indicates that these three treatments all preferentially enhanced muscle protein deposition compared to the silage-fed animals and corroborates the proportional muscle 
weight data $(\mathrm{g} / \mathrm{kg} \mathrm{LW}$, Table 2). The fact that FPG in the muscles of the silage-alone animals was less than fractional gain in body weight may reflect the low protein: high fat in the gain of these animals, a problem often associated with silage-fed cattle (Lonsdale, 1976).

\section{Protein turnover measurements}

An increase in muscle protein accretion can occur through an increase in protein synthetic rate, or a reduction in degradation rate, or a combination of both processes. Measurements of FSR were made in an attempt to identify the mechanisms by which fishmeal, oestradiol and cimaterol increase muscle growth. Although a number of methods for measuring FSR exist, the continuous infusion method remains a widely-used technique for measuring rates of protein synthesis, especially in large animals where the quantity of isotope and number of animals required for the flooding-dose method is prohibitive. However, it does suffer from the uncertainty of whether the plasma free tyrosine or the intracellular free tyrosine alone represents the true precursor pool for the amino-acyl t-RNA. Thus, the FSR values are generally given as a range approximating to the minimum and upper estimates of protein synthesis. The lower SRA of the intracellular free pool and, hence, the higher estimate of FSR, is due to dilution with unlabelled tyrosine arising from the intracellular degradation of muscle protein. In some reports there appears to be little difference (about $10 \%$ ) between the FSR estimates based on the plasma pool and those determined from the intracellular pool (e.g. Lobley et al. 1980), but in many others (e.g. Bryant \& Smith, 1982; Eisemann et al. 1989) and in the present study a difference of $>50 \%$ in the determinations based on the two precursor pools is seen.

Measurement of protein synthetic rates in large animals in vivo is difficult and tends to limit the number of animals which can be used in such studies. This, combined with the inherent variability between individuals, often causes problems in designs where treatment comparisons are made between rather than within animals, in so much as this variability may prevent differences between treatments attaining statistical significance although biological trends are apparent. Consequently there are few published reports of FSR measurements in cattle. The FSR values obtained for the three muscles from control animals in the present study, however, $(0 \cdot 7-2 \cdot 7 \% / \mathrm{d})$ are similar to those determined by Lobley et al. (1980) $(0 \cdot 8-2 \cdot 1 \% / d)$ and Eisemann et al. (1989) $(0 \cdot 6-2 \cdot 2 \% /$ d) in slightly older cattle.

Some workers have reported variations in the protein synthetic capacity of different muscles in sheep (Bryant \& Smith, 1982; Bohorov et al. 1987; Hunter et al. 1987), but in the present experiment no differences in the FSR of the three muscles were observed for the control diet. Variations in the response of different muscles to applied treatments have also been reported (Bohorov et al. 1987; Pell \& Bates, 1987) and consequently, in the present study, three different muscles were examined in order to establish if a differential response between muscles to the three treatments imposed had occurred. All animals receiving fishmeal, with or without oestradiol implantation, showed increased protein synthesis rates in all three muscles compared with control animals, in agreement with the finding of Garlick et al. (1975) in rat skeletal muscles that protein synthetic rates were sensitive to the level of protein in the diet. Muscle protein deposition was markedly increased in these animals and from the results obtained it would appear that a major contribution to this effect was an increase in FSR, but in the absence of values for fractional degradation rate, the possibility of a concurrent reduction in protein degradation cannot be ruled out.

Animals implanted with oestradiol showed no increase in muscle protein FSR over nonimplanted animals (both given fishmeal) but FPG tended to be higher which would suggest 
that the increased muscle accretion in the implanted animals may have occurred through a reduction in protein degradation rate. Great caution must be observed in drawing such a conclusion, however, as the small difference in FPG between these two treatment groups (indeed, between all 4 treatment groups, Table 5) may be less than can be reasonably detected by changes in FSR, thus making it difficult to determine unequivocally whether protein breakdown or synthesis has accounted for the treatment effect. The mode of action of oestradiol is unknown but endogenous growth hormone secretion is reported to be enhanced in steers implanted with oestrogenic compounds (Gopinath \& Kitts, 1984) and, in animals on a high plane of nutrition, plasma IGF-1 concentrations are also increased (Breier et al. 1988 b). This might be expected to increase the rate of protein synthesis (Pell \& Bates, 1987; Eisemann et al. 1989), although no evidence for this was obtained in the present study. Some of the anabolic agents such as zeranol, trenbolone acetate and the combined trenbolone-oestradiol implant (Revalor) are believed to operate primarily by reducing protein degradation rate (Vernon \& Buttery, 1976; Sinnett-Smith et al. 1983; Bohorov et al. 1987).

A reduction in protein degradation is also believed by many to be the predominant mechanism through which $\beta$-agonists increase muscle accretion where no increase in protein synthetic rate has been detected (Reeds et al. 1986; Bohorov et al. 1987). However, some reports have indicated that they act in part by increasing protein synthetic rate (Emery et al. 1984; Claeys et al. 1989). The results of the present study provide evidence for both an increase in protein synthetic rate and a reduction in protein degradation rate. Increased FSR were observed in the 1 . dorsi and $v$. lateralis muscles (particularly those based on the intracellular pool) whilst the FSR in the non-responding semitendinosus muscle was similar to that of control animals. The proportion of synthesized protein which was deposited tended to be increased, especially in the v. lateralis muscle, suggesting a decrease in protein degradation. However, as indicated previously, protein degradation rates are difficult to determine directly. In the present experiment, a crude estimate of the rate of overall skeletal muscle degradation was obtained from the excretion of $N^{r}$. methylhistidine and expressed relative to that of creatinine, an index of skeletal muscle mass (Forbes \& Bruining, 1976). $N^{\mathrm{r}}$-methylhistidine is released on catabolism of myofibrillar protein from skeletal muscle and in terms of being quantitatively excreted, its use as an index of muscle protein degradation has been validated for cattle (Harris \& Milne, 1981). However, there is evidence in rats that contractile proteins from non-skeletal muscle sources, particularly the intestine, comprise a significant proportion of the total urinary methylhistidine excretion and, thus, this technique cannot be regarded as an unequivocal indication of protein degradation in skeletal muscle (Millward \& Bates, 1983). Nevertheless, the results of the present trial indicated that $N^{\mathrm{r}}$-methylhistidine:creatinine excretion rate was significantly reduced in cimaterol-treated animals. A similar reduction was reported in calves fed on milk-substitute containing clenbuterol for $58 \mathrm{~d}$ (Williams et al. 1987). However, as the visceral protein mass of the treated calves was shown to be lower than that of the controls, it is possible that this may have at least partly contributed to the reduced $N^{\mathrm{T}}$-methylhistidine excretion observed by these authors.

In conclusion, observations from the present study indicate that fishmeal, oestradiol and cimaterol all increase muscle mass but the mechanism by which this is effected varies with the treatment imposed. The results clearly support the earlier findings of Gill et al. (1987) and, in part, provide an explanation of the mechanisms involved.

The authors are grateful to Boehringer Ingelheim Vetmedica, GmbH for the gift of cimaterol, and to Elanco Products Ltd for supplying the oestradiol implants. The assistance of John Corbett with the carcass dissections, David Bozon and David Howson with the 
methylhistidine and fat analyses respectively, and Ann Walsh for the gas-liquid chromatographic fatty acid analysis is gratefully acknowledged. This work is supported by an Agricultural and Food Research Council Link Grant.

\section{REFERENCES}

Atkin, G. E. \& Ferdinand, W. (1970). Accelerated amino acid analysis : studies on the use of lithium citrate buffers and the effect of n-propanol, in the analysis of physiological fluids and protein hydrolyzates. Analytical Biochemistry 38, 313-329.

Beermann, D. H., Fishell, V. K. Hogue, D. E., Ricks, C. A. \& Dalrymple, R. H. (1985). Effects of the repartitioning agent, cimaterol (CL263,780) on skeletal muscle fibre type and fibre hypertrophy in lambs. Journal of Animal Science 61, Suppl. 1, 254 Abstr.

Beever, D. E., Gill, M., Dawson, J. M. \& Buttery, P. J. (1990). Effect of fishmeal on the digestion of grass silage by growing cattle. British Journal of Nutrition $\mathbf{6 3}, 489-502$.

Bohorov, O., Buttery, P. J., Correia, J. H. R. D. \& Soar, J. B. (1987). The effect of the $\beta$-2-adrenergic agonist clenbuterol or implantation with oestradiol plus trenbolone acetate on protein metabolism in wether lambs. British Journal of Nutrition 57, 99-107.

Breier, B. H., Gluckman, P. D. \& Bass, J. J. (1988a). The somatotrophic axis in young steers: influence of nutritional status and oestradiol-17 $\beta$ on hepatic high- and low-affinity somatotrophic binding sites. Journal of Endocrinology 116, 169-177.

Breier, B. H., Gluckman, P. D. \& Bass, J. J. (1988b). Influence of nutritional status and oestradiol-17 $\beta$ on plasma growth hormone, insulin-like growth factors-I and -II and the response to exogenous growth hormone in young steers. Journal of Endocrinology 118, 243-250.

Bryant, D. T. W. \& Smith, R. W. (1982). Protein synthesis in muscle of mature sheep. Journal of Agricultural Science 98, 639-643.

Christie, W. W. (1973). Lipid Analysis, pp. 108-112. Oxford: Pergamon Press.

Claeys, M. C., Mulvaney, D. R., McCarthy, F. D., Gore, M. T., Marple, D. N. \& Sartin, J. L. (1989). Skeletal muscle protein synthesis and growth hormone secretion in young lambs treated with clenbuterol. Journal of Animal Science 67, 2245-2254.

Dawson, J. M., Bruce, C. I., Buttery, P. J., Gill, M. \& Beever, D. E. (1988). Protein metabolism in the rumen of silage-fed steers: effect of fishmeal supplementation. British Journal of Nutrition 60, 339-353.

Dawson, J. M., Buttery, P. J., Beever, D. E., Gill, M., Lammiman, M. J., Soar, J. B. \& Essex, C. P. (1987). Rates of muscle protein synthesis in silage-fed steers with manipulated carcass composition. In Proceedings of the 5 th International Symposium on Protein Metabolism and Nutrition, European Association for Animal Production, Publication no. 35, pp. 52-53 [W. Brauer, editor]. Rostock: Wissenschaftliche Zeitschrift der Wilhelm-Pieck Universität.

Eisemann, J. H., Hammond, A. C. \& Rumsey, T. S. (1989). Tissue protein synthesis and nucleic acid concentrations in steers treated with somatotropin. British Journal of Nutrition 62, 657-671.

Emery, P. W., Rothwell, N. J., Stock, M. J. \& Winter, P. D. (1984). Chronic effects of $\beta 2$-adrenergic agonists on body composition and protein synthesis in the rat. Bioscience Reports 4, 83-91.

Folch, J., Lees, M. \& Sloane Stanley, G. H. (1957). A simple method for the isolation and purification of total lipids from animal tissues. Journal of Biological Chemistry 226, 497-509.

Forbes, G. B. \& Bruining, G. J. (1976). Urinary creatinine excretion and lean body mass. American Journal of Clinical Nutrition 29, 1359-1366.

Forsberg, N. E., Nassar, A. R. \& Dalrymple, R. H. (1987). Cimaterol reduces Cathepsin B activity in sheep skeletal muscle. Federation Proceedings 46, 1176 Abstr.

Garlick, P. J. \& Marshall, I. (1972). A technique for measuring brain protein synthesis. Journal of Neurochemistry 19, $577-583$.

Garlick, P. J., Millward, D. J. \& James, W. P. T. (1973). The diurnal response of muscle and liver protein synthesis in vivo in meal-fed rats. Biochemical Journal 136, 935-945.

Garlick, P. J., Millward, D. J., James, W. P. T. \& Waterlow, J. C. (1975). The effect of protein deprivation and starvation on the rate of protein synthesis in tissues of the rat. Biochimica et Biophysica Acta 414, 71-84.

Gill, M., Beever, D. E., Buttery, P. J., England, P., Gibb, M. J. \& Baker, R. D. (1987). The effect of oestradiol$17 \beta$ implantation on the response in voluntary intake, live-weight gain and body composition, to fishmeal supplementation of silage offered to growing calves. Journal of Agricultural Science, Cambridge 108, 9-16.

Gopinath, R. \& Kitts, W. D. (1984). Growth hormone secretion and clearance rate in growing beef steers implanted with oestrogenic anabolic compounds. Growth 48, 499-514.

Harris, C. I. \& Milne, G. (1981). The urinary excretion of $N$-methyl histidine by cattle: validation as an index of muscle protein breakdown. British Journal of Nutrition 45, 411-422.

Hunter, R. A., Davey, J. B. \& Buttery, P. J. (1987). Fractional rate of protein synthesis in liver and in individual muscles of lambs: effect of time of sampling following the use of the continuous infusion technique. Journal of Agricultural Science, Cambridge 108, 511-514.

Jackson, M. J., Roberts, J. \& Edwards, R. H. T. (1988). Dietary fish oil supplementation modifies rat skeletal 
muscle fatty acid composition but does not influence the response of muscles to experimental damage. Proceedings of the Nutrition Society 47, 32A.

Kim, Y.S., Lee, Y. B. \& Ashmore, C. R. (1988). Cimaterol-induced growth in rats: growth pattern and biochemical characteristics. Growth, Development and Aging 52, 4l-46.

Kim, Y.S., Lee, Y. B. \& Dalrymple, R. H. (1987). Effect of the repartitioning agent cimaterol on growth, carcass and skeletal muscle characteristics in lambs. Journal of Animal Science 65, 1392-1399.

Lobley, G. E., Milne, V., Lovie, J. M., Reeds, P. J. \& Pennie, K. (1980). Whole body and tissue protein synthesis in cattle. British Journal of Nutrition 43, 491-502.

Lonsdale, C. (1976). The effect of season of harvest on the utilisation by young cattle of dried grass given alone or as a supplement to silage. $\mathrm{PhD}$ thesis, University of Reading.

Miller, M. F., Garcia, D. K., Coleman, M. E., Ekeren, P. A., Lunt, D. K., Wagner, K. A., Procknor, M., Welsh, T. H. Jr \& Smith, S. B. (1988). Adipose tissue, longissimus muscle and anterior pituitary growth and function in clenbuterol-fed heifers. Journal of Animal Science 66, 12-20.

Millward, D. J. \& Bates, P. C. (1983). 3-Methylhistidine turnover in the whole body, and the contribution of skeletal muscle and intestine to urinary 3-methylhistidine excretion in the adult rat. Biochemical Journal 214, 607-615.

Moser, R. L., Dalrymple, R. H., Cornelius, S. G., Pettigrew, J. E. \& Allen, C. E. (1986). Effect of cimaterol (CL 263,780 ) as a repartitioning agent in the diet for finishing pigs. Journal of Animal Science 62, 21-26.

Nicholas, G. A., Lobley, G. E. \& Harris, C. I. (1977). Use of the constant infusion technique for measuring rates of protein synthesis in the New Zealand White rabbit. British Journal of Nutrition 38, I-17.

Osborne, D. R. \& Voogt, P. (1978). The Analysis of Nutrients in Foods, pp. 156-158. London: Academic Press.

Owen, J. A., Iggo, B., Scandrett, F. J. \& Stewart, C. P. (1954). The determination of creatinine in plasma or serum, and in urine: a critical examination. Biochemical Journal 58, 426-437.

Pell, J. M. \& Bates, P. C. (1987). Collagen and non-collagen protein turnover in skeletal muscle of growth hormone-treated lambs. Journal of Endocrinology 115, RI-R4.

Pell, J. M., Gill, M. \& Beever, D. E. (1989). Variability of responsiveness to growth hormone in ruminants : nutrient interactions. In Use of Somatotropin in Livestock Production, [K. Sejrsen, M. Vestergaard and A. NeimannSorensen, editors]. London: Elsevier Applied Science.

Quirke, J. F., Allen, P., Moloney, A. P., Sommer, M., Hanrahan, J. P., Sheehan, W. \& Roche, J. F. (1988). Effects of the beta-agonist cimaterol on blood metabolite and hormone concentrations, growth and carcass composition in finishing Friesian steers. Journal of Animal Physiology and Animal Nutrition 60, 128-136.

Reeds, P. J., Hay, S. M., Dorwood, P. M. \& Palmer, R. M. (1986). Stimulation of muscle growth by clenbuterol: lack of effect on muscle protein biosynthesis. British Journal of Nutrition 56, 249-258.

Ricks, C. A., Dalrymple, R. H., Baker, P. K. \& Ingle, D. L. (1984). Use of a $\beta$-agonist to alter fat and muscle deposition in steers. Joumal of Animal Science 59, 1247-1255.

Sinnett-Smith, P. A., Dumelow, N. W. \& Buttery, P. J. (1983). Effects of trenbolone acetate and zeranol on protein metabolism in male castrate and female lambs. British Journal of Nutrition 50, 225-234.

Vernon, B. G. \& Buttery, P. J. (1976). Protein turnover in rats treated with trenbolone acetate. British Journal of Nutrition 36, 575-579.

Waalkes, T. P. \& Udenfriend, S. (1957). A fluorometric method for the estimation of tyrosine in plasma and tissues. Journal of Laboratory and Clinical Medicine 50, 733-736.

Williams, P. E. V., Pagliani, L., Innes, G. M., Pennie, K., Harris, C. I. \& Gaithwaite, P. (1987). Effects of a $\beta$-agonist (clenbuterol) on growth, carcass composition, protein and energy metabolism of veal calves. British Journal of Nutrition 57, 417-428. 